\title{
Effects of Insulin and Glucose Concentrations on Glucose Utilization in Fetal Sheep
}

\author{
WILLIAM W. HAY, JR., HUEI K. MEZNARICH, JANE E. DIGIACOMO, KATHRYN HIRST, AND \\ GARY ZERBE \\ Division of Perinatal Medicine, Departments of Pediatrics and Physiology [W.W.H., H.K.M., J.E.D.] and the \\ Division of Biometrics [K.H., G.Z.], University of Colorado School of Medicine, Denver, Colorado 80262
}

\begin{abstract}
Glucose and insulin clamp experiments were performed in vivo in chronically catheterized, late-gestation fetal lambs to quantify the effects of glucose and insulin on fetal glucose metabolism. Fetal glucose uptake from the placenta via the umbilical circulation (umbilical glucose uptake) was measured by application of the Fick principle, and fetal glucose utilization rate (GUR) was measured using $\left[\mathrm{U}^{1{ }^{14}} \mathrm{C}\right.$ glucose tracer. Fetal plasma insulin concentrations ranged from 2 to $119 \mu \mathrm{U} \cdot \mathrm{ml}^{-1}$ and fetal blood glucose concentrations ranged from 7.3 to $62.6 \mathrm{mg} \cdot \mathrm{dl}^{-1}$. GUR varied from 2.82 to $15.12 \mathrm{mg} / \mathrm{min} / \mathrm{kg}$ and the exogenous glucose entry rate (umbilical glucose uptake + glucose infusion) varied from 2.46 to $13.95 \mathrm{mg} / \mathrm{min} / \mathrm{kg}$. The mean GUR [6.53 $\pm 0.28(\mathrm{SEM}) \mathrm{mg} / \mathrm{kg} / \mathrm{min}]$ was not different from the mean exogenous glucose entry rate [6.29 \pm $0.30(\mathrm{SEM}) \mathrm{mg} / \mathrm{kg} / \mathrm{min}$. Multiple linear regression analysis on a glucose-by-insulin surface demonstrated a best-fit model of fetal glucose utilization following the quadratic equation: GUR $=-0.322+[0.289$ (glucose) $]+[0.108$

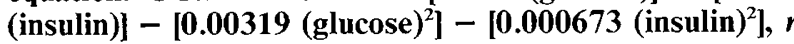
$=0.883$ (all terms significant at $p<0.02$ ). This model predicted a GUR $R_{\max }$ of $10.56 \mathrm{mg} / \mathrm{min} / \mathrm{kg}$ at blood glucose concentration $=45.3 \mathrm{mg} / \mathrm{dl}$ and plasma insulin concentration $=80 \mu \mathrm{U} / \mathrm{ml}$ and $\mathrm{Km}$ values for blood glucose concentration and plasma insulin concentration of $20.6 \mathrm{mg} / \mathrm{dl}$ and $10 \mu \mathrm{U} / \mathrm{ml}$, respectively. According to this model, the glucose and insulin effects were additive. Furthermore, change in GUR was not proportionate to change in glucose concentration, accounting for a decreasing metabolic clearance rate at higher glucose concentrations. These results demonstrate the three-dimensional nature of the simultaneous additive effects of glucose and insulin on glucose utilization. These results also serve to emphasize that comparative studies of insulin and glucose metabolism in fetal lambs must be conducted at similar concentrations of glucose to avoid inaccurate estimates of the magnitude of insulin effect on glucose metabolism. (Pediatr Res 23: 381-387, 1988)
\end{abstract}

\section{Abbreviations}

G, blood glucose concentration I, plasma insulin concentration UGU, umbilical glucose uptake GUR, glucose utilization rate GER, glucose entry rate

Received August 17, 1987; accepted December 9, 1987

Correspondence and reprint requests William W. Hay, Jr., M.D., Associate Professor, Department of Pediatrics, Box B-195, University of Colorado Health Sciences Center, 4200 East Ninth Avenue, Denver, CO 80262.

Supported by NIH Project Grant DK-35836, NIH Program Grant HD-00781, and NIH Center Grant HD-20761. H.K.M. and J.E.D. were supported by NIH Training Grant HD-07186.
Recently, we demonstrated that the maximum response of the fetal lamb to insulin infusion was a doubling of fetal glucose utilization rate (4). These studies were carried out using a glucose clamp technique in which individual fetuses were studied at "euglycemia," defined as the control (preinsulin) level of glucose. These glucose concentrations covered the normal range of glucose concentrations for well-fed Columbia-Rambouillet sheep, $15-25 \mathrm{mg} / \mathrm{dl}$ whole blood. Over this range of glucose concentration, glucose utilization rate was positively correlated with glucose concentration both at normal and high levels of insulin. These results strongly suggested that ovine fetal glucose metabolism could be more fully characterized according to effects of both insulin and glucose concentrations. To date, however, there has been little direct experimental evidence provided to complete such characterization of fetal insulin and glucose effects. As a result, the response of fetal glucose metabolism to changes of fetal glycemia and fetal insulinemia, produced by changes in maternal glucose concentration that occur with important clinical problems such as diabetes mellitus or fasting-induced hypoglycemia, have not been adequately quantified.

Therefore, the present studies were conducted to measure glucose metabolism in the fetal lamb at different levels of plasma insulin and blood glucose concentration in order to provide a more complete description of how insulin and glucose act together to regulate fetal glucose metabolism. In these studies, glucose and insulin clamp experiments were performed in vivo in unstressed, chronically catheterized fetal lambs. Plasma insulin concentrations ranged from 2 to $119 \mu \mathrm{U} / \mathrm{ml}$ and blood glucose concentrations ranged from 7.3 to $62.6 \mathrm{mg} / \mathrm{dl}$. Fetal insulin sensitivity was quantified as the change in fetal glucose utilization rate for a change in fetal arterial plasma insulin concentration.

\section{MATERIALS AND METHODS}

Animal preparation. Pregnant Columbia-Rambouillet ewes were studied between 130 and 145 days of gestation. The ewes were fasted for 2 days before surgery. Surgery was performed under intravenous pentobarbital sedation $(5 \mathrm{mg} / \mathrm{kg})$ and pontocaine spinal anesthesia (6 mg in hypertonic glucose). Using a standard hysterotomy approach, polyvinyl catheters for infusion of antipyrine, radioactive glucose, glucose, and insulin were placed in the fetal femoral veins via pedal veins. Catheters for blood sampling were placed in the fetal abdominal aorta via a pedal artery and into the common umbilical vein. All catheters were tunneled subcutaneously through a flank incision on the ewe and kept within a plastic pouch attached to the ewe's skin. The catheters were flushed every other day with heparinized $0.9 \%$ $\mathrm{w} / \mathrm{v}$ sodium chloride ( $30 \mathrm{U}$ heparin $/ \mathrm{ml}$ of $0.9 \%$ sodium chloride). The ewes were allowed to recover after surgery for at least 5 days before study. They were kept in carts and given an ad libitum diet of alfalfa pellets, water, and mineral supplement. The ewes were kept in a room with the temperature controlled between 
$15-20^{\circ} \mathrm{C}$. At least two sheep were always kept together for company. At the end of the studies, each animal was sacrificed with a rapid intravenous infusion of $T-61$ (Taylor Pharmaceutical Co., Decatur, IL). The fetus was autopsied for measurement of weight and for observation of catheter location.

Blood sampling, chemical, and analytical methods. Umbilical venous and arterial blood samples were drawn simultaneously into plastic syringes lined with a mixture of EDTA and sodium fluoride. These samples were used for determination of glucose, radioactive glucose, radioactive carbon dioxide, insulin, and antipyrine concentrations (total of $3 \mathrm{ml}$ per catheter per sample) using chemical methods previously described (9-11). At the same time whole blood $(200 \mu \mathrm{l})$ was drawn anaerobically into glass capillaries lined with dried heparin and sodium fluoride. The capillary samples were used for measurement of blood oxygen capacity and percent oxygen saturation using a Radiometer OSM2 hemoximeter in order to calculate blood oxygen content. Plasma for insulin concentration was immediately separated from blood in a refrigerated centrifuge and frozen at $-70^{\circ} \mathrm{C}$ until analysis. Whole blood glucose concentration for maintaining the glucose clamp was measured with a Yellow Springs glucose analyzer model $23 \mathrm{~A}$ on blood samples taken every $10 \mathrm{~min}$ from the fetal arterial catheter. The glucose analyzer was calibrated to an accuracy of $\pm 1.0 \mathrm{mg} / \mathrm{dl}$. Samples were analyzed in duplicate and the average value was used for the glucose clamp technique $(4,5)$. A standard with a concentration of glucose close to that in the blood was analyzed before each blood sample and used to keep the instrument calibrated throughout the study.

Infusates. Glucose for infusion consisted of dextrose $10 \%$ and dextrose $20 \%$ (weight per volume in water, Travenol Laboratories, Inc., Deerfield, IL). The glucose concentrations in these solutions were measured at 91 and $183 \mathrm{mg} / \mathrm{ml}$, respectively, using the glucose oxidase method described below. Antipyrine for infusion was prepared as a $10 \%$ solution in distilled water and was infused at about $10 \mathrm{mg} / \mathrm{min}$. Insulin (pure pork insulin, Eli Lilly Corporation, Indianapolis, IN) was diluted in a mixture of $0.9 \% \mathrm{w} / \mathrm{v}$ sodium chloride $(30 \mathrm{ml})$ and maternal sheep plasma $(7 \mathrm{ml})$ and infused at rates ranging from about 0.2 to about 1.0 $\mathrm{mU} / \mathrm{min} / \mathrm{kg}$ fetal weight. [U- ${ }^{14} \mathrm{C}$ ]glucose was obtained from ICN Radiochemicals (Irvine, CA) and mixed with $0.9 \% \mathrm{w} / \mathrm{v}$ sodium chloride to provide a solution that contained about $12 \mu \mathrm{Ci} / \mathrm{ml}$ and was infused into a fetal femoral vein at about $1.0 \mu \mathrm{Ci} / \mathrm{min}$. The concentration of $\left[\mathrm{U}-{ }^{14} \mathrm{C}\right]$ glucose in this infusate was the same before and after the study and was not altered by infusion for $4 \mathrm{~h}$ through a standard polyvinyl catheter. All infusions were given with Sage model 355 syringe infusion pumps.

Experimental design. At time zero, the primed, constant infusions of antipyrine and radioactive glucose were started into the fetus. The prime dose of radioactive glucose was estimated according to an assumed tracer glucose distribution space of $70 \%$ of fetal weight, based on bolus tracer experiments (12) and on preliminary trials in our laboratory. This primed, constant infusion method has been shown to produce a constant specific activity in the fetus after $60-75$ min of infusion $(5,7,9)$. Between 90 and $120 \mathrm{~min}$ of tracer infusion (control sampling period), four sets of simultaneous umbilical venous and arterial blood samples were withdrawn at 10 -min intervals for glucose concentration, radioactive glucose concentration, radioactive carbon dioxide concentration, oxygen content, and antipyrine concentration. Blood samples for insulin concentration were obtained from the arterial catheter only. An equal volume of maternal blood was used to replace each fetal blood sample.

At the end of the control period insulin was infused into the fetus using a primed, constant infusion. The prime dose was based on an assumed fetal insulin space of $15 \%$ of fetal body weight. This regimen produced relatively constant fetal arterial insulin concentrations by $30 \mathrm{~min}$ of infusion $(4,5)$.

During the insulin infusion, fetal arterial blood glucose was maintained at different desired levels ranging from the average control level to about $50 \mathrm{mg} / \mathrm{dl}$ using glucose clamp technique modified for use in fetal sheep as previously described $(4,5)$ from the technique introduced by DeFronzo et al. (13). Subsequent measurements of insulin, glucose, radioactive glucose, radioactive carbon dioxide, oxygen content, and antipyrine concentrations were made four times at 10-min intervals between 120 and 150 min after starting the insulin infusion (hyperinsulinemia sampling period). Only two such periods [one control and one insulin \pm glucose period] were studied on a given day.

Calculations. Umbilical blood flow was calculated by the steady-state diffusion technique (11). Calculations of glucose entry and utilization were made using steady-state equations. During the control sampling period, net fetal glucose uptake from the placenta was calculated by the Fick principle (umbilical blood flow times the umbilical venous-arterial blood glucose concentration difference). During the glucose infusion and insulin infusion sampling periods, total net fetal glucose uptake was calculated as the sum of net fetal glucose uptake from the placenta via the umbilical circulation plus the glucose infused intravenously into the fetus. The rate of intravenous glucose infusion was calculated as the average of the four 10-min infusion rates during the 30 -min sampling periods. Fetal glucose utilization was calculated as the net fetal tracer uptake rate divided by the fetal arterial blood glucose specific activity (9).

Statistics. Steady-state was determined in each 30-min sampling period as less than a $\pm 5 \%$ variation of the four sample values around the mean value for the entire sampling period with no consistent trend to increase or decrease.

The effects of glucose and insulin concentration on fetal glucose utilization rate were analyzed using the SAS PROC GLM computer program to determine a "best-fit" multiple linear regression on a glucose-by-insulin surface. Differences between groups were assessed by analysis of variance and were considered significant at $p<0.05$.

All values are expressed as mean \pm SEM. The means, SE, analyses of variance, and regressions all account for the multiple and variable number of observations per animal.

\section{RESULTS}

Of the 27 animals studied, nine completed three study periods (control, hyperinsulinemia-euglycemia, and hyperinsulinemiahyperglycemia) and 18 completed two study periods (five with control plus hyperinsulinemia-euglycemia and 13 with control plus hyperinsulinemia-hyperglycemia).

Each sampling period lasted $30 \mathrm{~min}$ and occurred at least 120 min after achieving each new steady-state level of insulin and glucose. Mean ( \pm SEM) values for glucose, ${ }^{14} \mathrm{C}$-glucose, ${ }^{14} \mathrm{CO}_{2}$, and insulin during each sampling period are shown in Figure 1, demonstrating achievement of steady-state (studies are grouped as: A) control; B) hyperinsulinemia-euglycemia; and C) hyperinsulinemia-hyperglycemia).

Umbilical cord blood flow did not change significantly from one study period to the next within each animal's series of studies (Table 1). Glucose utilization rate for all studies $(n=79$ studies on 27 sheep) did not differ significantly $(p>0.5)$ from the mean total exogenous glucose supply (umbilical glucose uptake plus fetal intravenous glucose infusion), demonstrating the absence of measurable fetal endogenous glucose production during these short-term changes in fetal glucose supply and concentration [GUR $=0.957+0.89$ (GER), $r=0.94]$. The mean GUR was $6.53 \pm 0.28 \mathrm{mg} / \mathrm{min} / \mathrm{kg}$ and the mean total exogenous glucose supply was $6.29 \pm 0.30 \mathrm{mg} / \mathrm{min} / \mathrm{kg}$.

The "best fit" model of fetal glucose utilization rate versus glucose concentration and insulin concentration followed the quadratic equation:

$$
\begin{gathered}
\text { GUR }=-0.322+[0.289 \times(\text { glucose })]+[0.108 \times(\text { insulin })] \\
-\left[0.00319 \times(\text { glucose })^{2}\right]-\left[0.000673 \times(\text { insulin })^{2}\right]
\end{gathered}
$$

There were two sources of variability in this "best fit" model: a residual (within subject) SD of $1.62 \mathrm{mg} / \mathrm{min} / \mathrm{kg}$ and an addi- 
tional between subject $\mathrm{SD}$ of $0.90 \mathrm{mg} / \mathrm{min} / \mathrm{kg}$, for a total $\mathrm{SD}$ of $1.85 \mathrm{mg} / \mathrm{min} / \mathrm{kg}$.

This multiple linear regression model explains $78 \%$ of the variability in GUR (multiple $r=0.883$ ). All of the terms in the model are significant at the $p<0.02$ level [(glucose) $=0.002$; $($ insulin $)=0.0001 ;(\text { glucose })^{2}=0.013 ;$ and $(\text { insulin })^{2}=0.009$ ] The total contribution of glucose is highly significant $(p=0.002)$ as is the total contribution of insulin $(p=0.003)$. Both glucose and insulin contribute about equally to the total sum of squares and appear to be equal partners statistically. Moreover, glucose and insulin appear to contribute additively to GUR; i.e. tests of a glucose-insulin interaction were nonsignificant $(p=0.08)$ and represented the least important of all factors affecting GUR. Individual data points for each value of GUR are plotted threedimensionally in Figure $2 A$. Figure $2 B$ presents the predicted GUR/glucose $x$ insulin surface, based on equation 1 . Twodimensional plots of GUR versus I at three different levels of $G$ and GUR versus $G$ at three different levels of $I$ are shown in Figures $3 A$ and $3 B$, respectively.
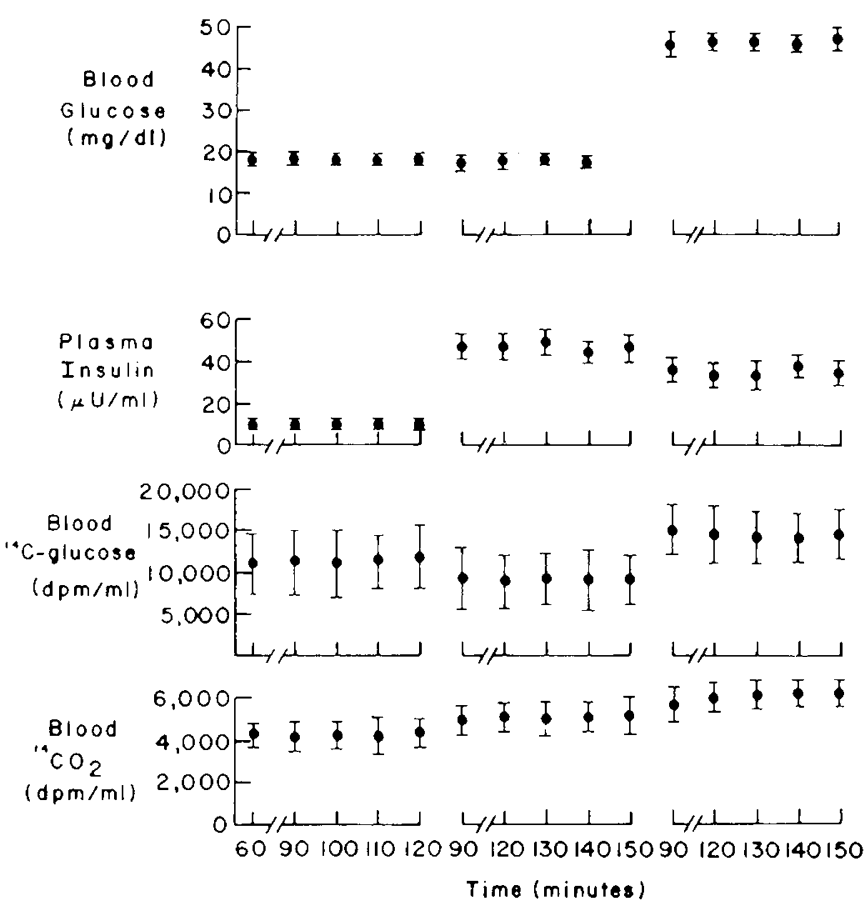

Fig. 1. Mean \pm SEM concentrations of glucose, insulin, radioactive glucose, and ${ }^{14} \mathrm{CO}_{2}$ at different times during the study periods, grouped arbitrarily as: A) control; B) hyperinsulinemia-euglycemia; and C) hyperinsulinemia-hyperglycemia.

\section{DISCUSSION}

The results herein demonstrate that in the mature fetal lamb both insulin and glucose affect the rate of fetal glucose utilization. These effects are dependent on the absolute concentrations of glucose and insulin, each acting independently. This independent action accounts for the two-dimensional parallel relationship of GUR versus (I) at different levels of $(G)$ and of GUR versus $(G)$ at different levels of $(\mathrm{I})$. The three-dimensional analysis serves to emphasize how fetal glucose and insulin, which change together, affect GUR additively. To the best of our knowledge, this is the first study to provide data that define such relationships among fetal glucose concentration, fetal insulin concentrations, and fetal glucose utilization rate.

In previous reports we have shown that at low and at high levels of insulin, glucose utilization varied significantly $(4,5)$. Part of this variability appeared to be due to differences in glucose concentration. Herein we confirm this assumption, showing that at any level of insulin, glucose utilization is directly dependent on the concentration of glucose.

Previously, we showed that at "euglycemia" ( $20 \mathrm{mg} / \mathrm{dl})$ in near term fetal lambs the maximum rate of glucose utilization was achieved at plasma insulin concentrations much greater than $80 \mu \mathrm{U} / \mathrm{ml}$ (average $\mathrm{I}=303 \mu \mathrm{U} / \mathrm{ml}$ ). This insulin-dependent maximum rate was $9.05 \mathrm{mg} / \mathrm{min} / \mathrm{kg}(5)$. Herein, at a fixed value of $\mathrm{G}=20 \mathrm{mg} / \mathrm{dl}$, GUR is maximized at $8.52 \mathrm{mg} / \mathrm{min} / \mathrm{kg}$ when $\mathrm{I}=80 \mu \mathrm{U} / \mathrm{ml}$. This GUR value is quite comparable to the predicted value of GUR at $\mathrm{I}=80 \mu \mathrm{U} / \mathrm{ml}$ and at $\mathrm{G}=20 \mathrm{mg} / \mathrm{dl}$ from the previous study. Similarly, at $\mathrm{I}=11$ (control period mean value), GUR $\max$ is $7.33 \mathrm{mg} / \mathrm{min} / \mathrm{kg}$ at $\mathrm{G}=45.3 \mathrm{mg} / \mathrm{dl}$ in the present study. Data in the present study can be analyzed similarly for the glucose plus insulin-dependent GUR kinetics. Setting $\mathrm{d} G U R / \mathrm{d} \mathrm{I}=0$ and $\mathrm{d} \mathrm{GUR} / \mathrm{d} \mathrm{G}=0$ (i.e. setting the first partial derivatives equal to zero), $\mathrm{GUR}_{\max }=10.56 \mathrm{mg} / \mathrm{min} / \mathrm{kg}$ at $\mathrm{G}=45.3 \mathrm{mg} / \mathrm{dl}$ and $\mathrm{I}=80 \mu \mathrm{U} / \mathrm{ml}$. Thus, for the mature fetal lamb $7.3-8.5 \mathrm{mg} / \mathrm{min} / \mathrm{kg}$ appears to represent the average maximum rate at which insulin up to $80 \mu \mathrm{U} / \mathrm{ml}$ and glucose at euglycemia can promote glucose metabolism. This value can be increased to about $10.6 \mathrm{mg} / \mathrm{min} / \mathrm{kg}$ when glucose is increased to $45 \mathrm{mg} / \mathrm{dl}$. At these values of $\mathrm{GUR}_{\max }$ the $\mathrm{Km}$ for glucosedependent GUR at euinsulinemia $(11 \mu \mathrm{U} / \mathrm{ml})$ is $11.8 \mathrm{mg} / \mathrm{dl}$, where $\mathrm{Km}$ is the glucose concentration at the GUR halfway between GUR at $\mathrm{G}=0 \mathrm{mg} / \mathrm{dl}, \mathrm{I}=11 \mu \mathrm{U} / \mathrm{ml}$, and $\mathrm{GUR}_{\max }$ at $\mathrm{G}=45 \mathrm{mg} / \mathrm{dl}$ and $\mathrm{I}=11 \mu \mathrm{U} / \mathrm{ml}$. Similarly, the $\mathrm{Km}$ for insulindependent GUR at euglycemia (18 mg/dl) is $24 \mu \mathrm{U} / \mathrm{ml}$, where $\mathrm{Km}$ is the insulin concentration at the GUR halfway between GUR at $\mathrm{G}=17.7 \mathrm{mg} / \mathrm{dl}, \mathrm{I}=0 \mu \mathrm{U} / \mathrm{ml}$, and $\mathrm{GUR}_{\max }$ at $\mathrm{G}=17.7$ $\mathrm{mg} / \mathrm{dl}$ and $\mathrm{I}=80 \mu \mathrm{U} / \mathrm{ml}$.

On the other hand, defining a $\mathrm{Km}$ for the three-dimensional glucose $\times$ insulin surface is more complex. At GUR halfway

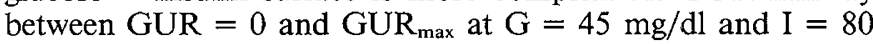
$\mu \mathrm{U} / \mathrm{ml}(10.56 \mathrm{mg} / \mathrm{min} / \mathrm{kg})$ there is a large variety of $\mathrm{G} \times \mathrm{I}$ pairs

Table 1. Glucose and insulin concentrations and glucose fluxes [mean (SEM)]

\begin{tabular}{|c|c|c|c|}
\hline & Control & $\begin{array}{l}\text { Hyperinsulinemia- } \\
\text { euglycemia }\end{array}$ & $\begin{array}{c}\text { Hyperinsulinemia- } \\
\text { hyperglycemia }\end{array}$ \\
\hline & A & $\mathrm{B}$ & $\mathrm{C}$ \\
\hline No. of sheep & 27 & 14 & 22 \\
\hline No. of studies & 34 & 19 & 26 \\
\hline Umbilical blood flow (ml/min/kg) & $198(11)$ & $203(13)$ & $202(12)$ \\
\hline Glucose (mg/dl) & $17.7(0.8)$ & $16.4(1.1)$ & $46.5^{*} \dagger(1.8)$ \\
\hline Umbilical glucose uptake $(\mathrm{mg} / \mathrm{min} / \mathrm{kg})$ & $4.34(0.24)$ & $4.15(0.35)$ & $-2.20^{*,} \dagger(0.63)$ \\
\hline Glucose infusion rate $(\mathrm{mg} / \mathrm{min} / \mathrm{kg})$ & & $2.36(0.28)$ & $10.70 \dagger(0.64)$ \\
\hline Glucose entry rate $(\mathrm{mg} / \mathrm{min} / \mathrm{kg})$ & $4.34(0.24)$ & $6.50^{*}(0.32)$ & $8.66^{*}+(0.53)$ \\
\hline Glucose utilization rate $(\mathrm{mg} / \mathrm{min} / \mathrm{kg})$ & $4.79(0.23)$ & $6.62 *(0.31)$ & $8.68^{*}+(0.56)$ \\
\hline
\end{tabular}

* Different from A, $p<0.05$.

$\uparrow$ Different from $\mathrm{B}, p<0.05$. 

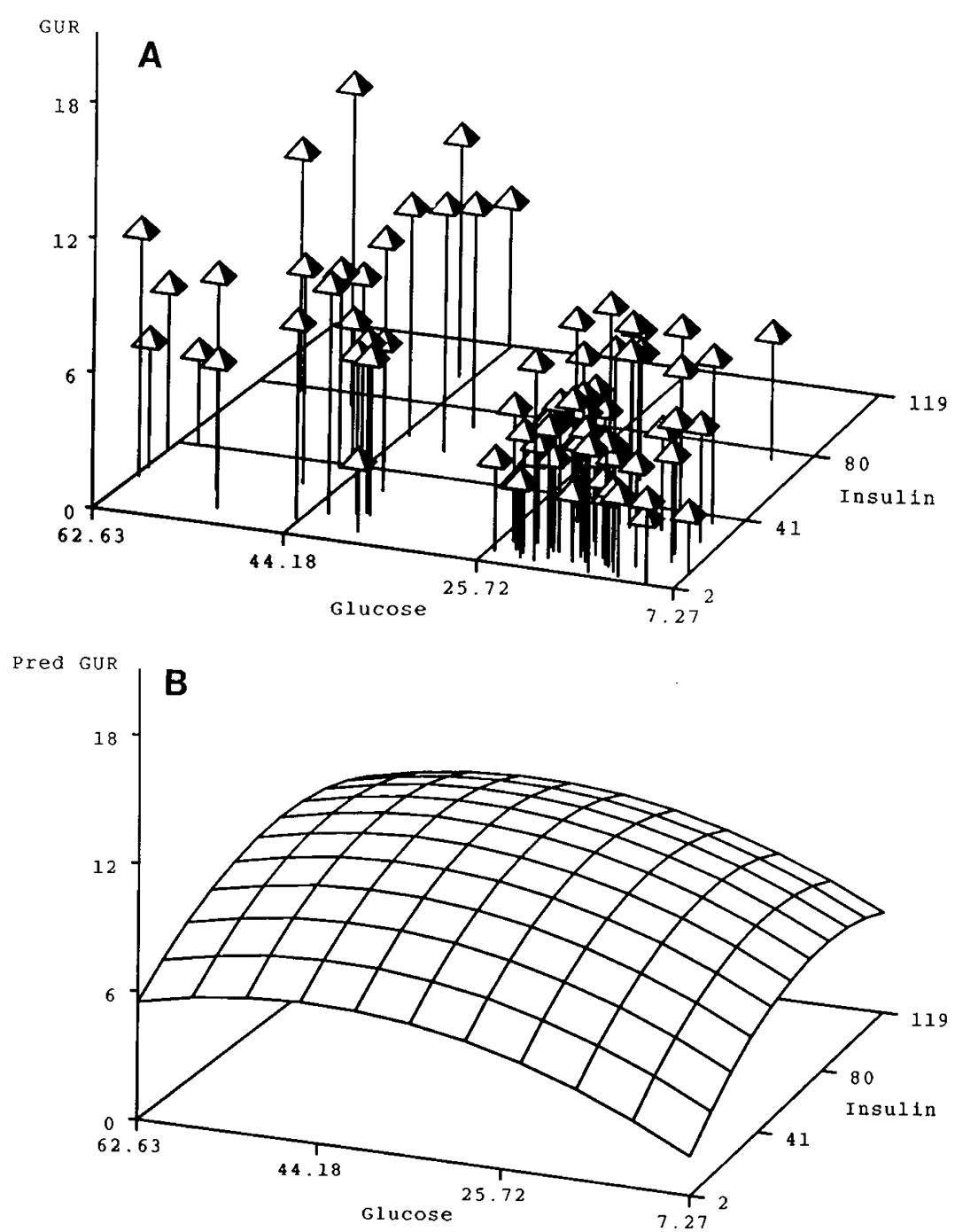

Fig. 2. $A$, three-dimensional plot of individual values of glucose utilization rate at different concentrations of insulin and glucose. $B$, predicted three-dimensional glucose $\times$ insulin surface using equation 1 (see "Results").

that could serve as a $\mathrm{G} \times \mathrm{I} \mathrm{Km}$. Inasmuch as, under normal circumstances, $\mathrm{I}$ is dependent on $\mathrm{G}$, a discrete value of $\mathrm{G}$ can be selected with its corresponding I to calculate $\mathrm{G} \times \mathrm{I} \mathrm{Km}$. Using the relationship between I and $G$ provided by Philipps et al. (8) $(\mathrm{I} \cong 0.465 \mathrm{G})$, the $\mathrm{G} \times \mathrm{I} \mathrm{Km}$ for the present data is $\mathrm{G}=20.6$ $\mathrm{mg} / \mathrm{dl}$ and $\mathrm{I}=10 \mu \mathrm{U} / \mathrm{ml}$. These values are remarkably similar to the control period ("normal") values for $\mathrm{G}(17.7 \mathrm{mg} / \mathrm{dl})$ and I $(11 \mu \mathrm{U} / \mathrm{ml})$ herein.

These data indicate that glucose transport into cells in the fetal lamb represents the rate-limiting process by which both glucose and insulin promote glucose metabolism. Glucose acts by affecting the extracellular-intracellular concentration gradient and thus applies to all glucose-consuming tissues. Insulin has been assumed to regulate glucose transport by increasing the number of functional transporters in the cell membrane of insulin-sensitive tissues without changing the affinity of the transporter for glucose. Such assumptions have been developed from studies in amphibia (14) and adult rat tissues (15), and whole body studies in adult humans (16) over the physiologic range of glucose and insulin. More recent studies in humans (17), that included the pharmacologic range for insulin, demonstrated an increasing $\mathrm{Km}$ at very high insulin concentrations, reflecting an apparent shift in the rate-limiting step from glucose transport to some step beyond transport. In vitro correlates are not available for fetal lamb tissues. However, Wilkening et al. (18) showed that pharmacologic levels of insulin $(600-1000 \mu \mathrm{U} / \mathrm{ml})$ in the fetal lamb produced the same maximum doubling of the isolated fetal hindlimb (largely representing skeletal muscle), comparable to our whole animal studies $(4,5)$.

At the mean control period insulin concentration of $11 \mu \mathrm{U} /$ $\mathrm{ml}$, the maximum predicted rate of glucose utilization is reduced to $7.33 \mathrm{mg} / \mathrm{min} / \mathrm{kg}$ or about $69 \%$ of the maximum GUR of $10.56 \mathrm{mg} / \mathrm{min} / \mathrm{kg}$. This observation suggests that the majority of glucose utilization is dependent primarily on the supply of glucose and secondarily is augmented by increasing concentrations of insulin. It cannot be determined from these data, however, whether the distribution of glucose utilization among fetal tissue shifts more to insulin-independent tissues (such as the liver and brain) as insulin concentration is reduced. Given the relatively small proportion of fetal glucose utilization accounted for by these tissues at normoinsulinemia and normoglycemia (approximately $20-25 \%$ ) (19-21), it appears unlikely that at zero insulin all of the glucose utilization would occur in these tissues. Instead, glucose uptake by all glucose-containing tissues likely continues, even in the absence of insulin, driven solely by the glucose concentration gradient-dependent diffusion across cell membranes.

From another perspective, using the two-dimensional analysis (Fig. 3), over the (G) range of $10-50 \mathrm{mg} / \mathrm{dl}$ and the (I) range of $10-80 \mu \mathrm{U} / \mathrm{ml}$, the $\mathrm{Km}$ for glucose-dependent GUR is about 11 $\mathrm{mg} / \mathrm{dl}$, about $33 \%$ less than the normal glucose concentration, and the $\mathrm{Km}$ for insulin-dependent GUR is about $23.5 \mu \mathrm{U} / \mathrm{ml}$, about $118 \%$ more than the normal insulin concentration (using the insulin assay as described herein). Furthermore, over the 

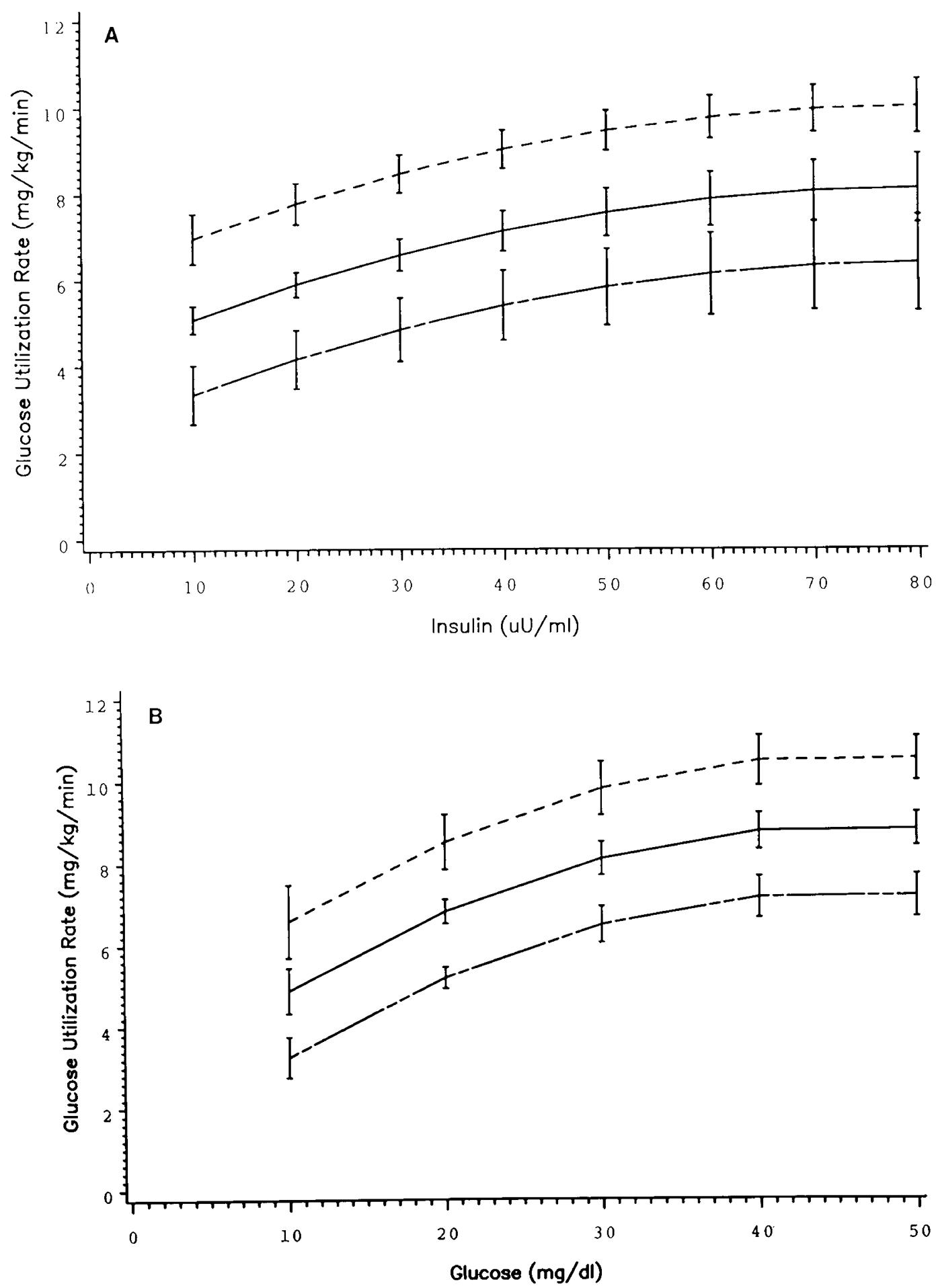

Fig. 3. A, two-dimensional plot of glucose utilization rate versus insulin concentration at three concentrations of glucose (10 mg/ dl-_-; $20 \mathrm{mg} / \mathrm{dl}-\ldots ; 50 \mathrm{mg} / \mathrm{dl}---)$ using equation 1 . GUR $=-0.322+[0.289$ (glucose) $]+[0.108$ (insulin) $]-\left[\left(0.00319\right.\right.$ (glucose) $\left.{ }^{2}\right]-$ [0.000673 (insulin) $\left.)^{2}\right], r=0.88 . B$, two-dimensional plot of glucose utilization rate versus glucose concentration at three concentrations of insulin (10 $\mu \mathrm{U} / \mathrm{ml}, \ldots \ldots ; 30 \mu \mathrm{U} / \mathrm{ml}, \ldots+; 80 \mu \mathrm{U} / \mathrm{ml},---)$ using equation 1 .

same ranges of $(G)$ and $(I)$, the slope of GUR versus $(G)(0.118$ $\mathrm{mg} / \mathrm{min} / \mathrm{kg}$ per $\mathrm{mg} / \mathrm{dl}$ ) is nearly 2 -fold more than the slope of GUR versus (I) $(0.062 \mathrm{mg} / \mathrm{min} / \mathrm{kg}$ per $\mu \mathrm{U} / \mathrm{ml})$ (Fig. 3). Together these data indicate that a change in fetal glucose concentration has a greater effect on GUR than does the accompanying change in insulin concentration. This would only be the case if glucose and insulin changed proportionately. Philipps et al. (8) have shown that the insulin-glucose relationship in mature fetal lambs is, in fact, nearly proportionate; by their data a change in insulin concentration averages about $95 \%$ of the simultaneous change in glucose concentration. Thus, from several perspectives, glucose utilization in the fetal lamb near term is regulated at physiologic concentrations by both glucose and insulin, but glucose exerts the dominant control. It is also interesting to note that the GUR versus $\mathrm{G}$ relationship of $0.118 \mathrm{mg} / \mathrm{min} / \mathrm{kg}$ per $\mathrm{mg} / \mathrm{dl}$ is quite close to the value of 0.091 found in preterm human newborn infants (22).

The dependence of GUR on $(\mathrm{G})$ and (I) is an important 
observation for several reasons. First, other investigations of the effect of insulin on glucose metabolism in fetal lambs have been conducted at different glucose concentrations (1-6). In such studies, measured or estimated rates of GUR were different, based on different levels of $\mathrm{G}$ rather than $\mathrm{I}$. For example, insulin infusions into fetal lambs produced GUR 30-50\% lower when $\mathrm{G}$ was allowed to decrease $(2,3)$ compared to GUR when $\mathrm{G}$ was maintained at control levels $(4,5)$. Second, different breeds of sheep appear to maintain unique levels of fetal glucose [e.g. normoglycemia in Columbia-Rambouillet fetal sheep is $18-20$ $\mathrm{mg} / \mathrm{dl}(8)$ whereas $10-14 \mathrm{mg} / \mathrm{dl}$ is more characteristic of Scottish Blackface (23) and Welsh Mountain fetal lambs (24)]. Among these breeds similar methodology has resulted in quite different estimates of fetal GUR and fetal endogenous glucose production rates. Third, fetal glucose concentration and glucose utilization rate vary directly with maternal glucose concentration (7) which can be quite different from sheep to sheep, dependent upon diet or experimental design. As shown in Figure $3 B$, GUR reaches a maximum rate as $(G)$ is increased; above a $(G)$ of $\sim 45 \mathrm{mg} / \mathrm{dl}$, there is no significant further increase in GUR with $(\mathrm{G})$. Thus, GUR is not proportionate to $(G)$. These observations are shown in Figure 4 which describes a decrease in fetal glucose metabolic clearance rate $(\mathrm{GUR} / \mathrm{G})$ with increasing glucose concentration.

In similar studies in adult humans, not only was GUR not proportionate to $G$, neither was $\Delta G U R / \Delta I$ (insulin sensitivity, where $\Delta$ signifies a unit change) proportionate to $\mathrm{G}$; i.e. at increasing values of $G$, insulin sensitivity increased. By analyzing data from three studies in adult humans, Bergman et al. (25) could not demonstrate a consistent nonproportionality between $\Delta \mathrm{GUR} / \mathrm{G} \cdot \Delta \mathrm{I}$ and $\mathrm{G}$, suggesting that $\Delta \mathrm{GUR} / \mathrm{G} \cdot \Delta \mathrm{I}$, called an "insulin sensitivity index," was a reasonably accurate approach to normalize the effect of $G$ on the GUR versus I relationship. Similarly, studies in adult humans reported by Best et al. (26) showed an increasing "glucose sensitivity" $(\Delta G U R / \Delta G)$ at increasing values of $I$. Together these results indicate that in adult humans, glucose and insulin interact to affect GUR; i.e. their combined effects are more than additive. These results stand in contrast to the additive-only effects of $G$ and I on GUR found in the fetal sheep in the present study, exemplified by the first derivatives of equation 1 :

$$
\begin{aligned}
& \mathrm{d} \text { GUR/d I }=0.108-0.001346 \mathrm{I} \\
& \mathrm{d} \text { GUR/d G }=0.289-0.00638 \mathrm{G}
\end{aligned}
$$

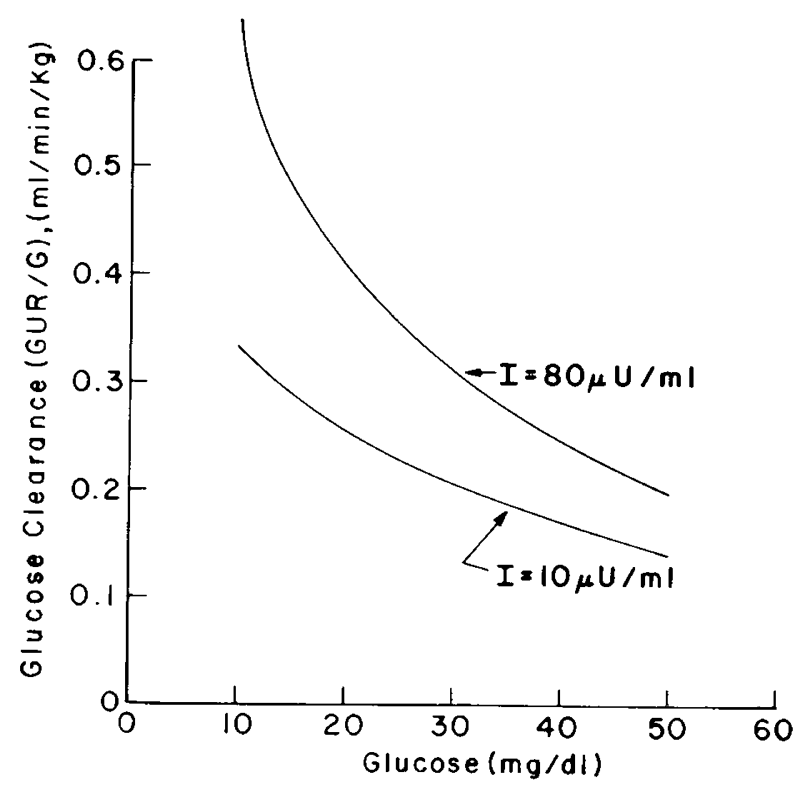

Fig. 4. Glucose clearance rate $[G U R /(G)]$ is compared with $G$ at two concentrations of insulin, demonstrating that GUR does not change proportionate to $(\mathrm{G})$.
These expressions demonstrate that, unlike adult humans, in fetal sheep d GUR/d I does not depend on $G$ and $d$ GUR/d G does not depend on $\mathrm{I}$.

The average linear slope of the GUR versus (I) relationship is $0.062 \mathrm{mg} / \mathrm{min} / \mathrm{kg}$ per $\mu \mathrm{U} / \mathrm{ml}$. This value is comparable to the value of 0.07 estimated from three fetal sheep studied at about $18 \mathrm{mg} / \mathrm{dl}$ fetal arterial blood glucose that we reported earlier (4). To the best of our knowledge these are the only data in fetal sheep that describe and quantify ovine fetal insulin sensitivity. Our preliminary results in adult female Columbia-Rambouillet sheep showed a GUR/I value of about 0.03 (27). Weeks et al. (28) also estimated that the insulin $\mathrm{Km}$ for glucose metabolism in adult male sheep ranged from 36 to $40 \mu \mathrm{U} / \mathrm{ml}$. These values are 50 to $66 \%$ higher than found in the fetal lambs herein. A major difference between fetal and adult insulin-sensitive tissues in sheep, therefore, is that insulin sensitivity is reduced in the adult. Furthermore, the lower adult insulin sensitivity occurs at a markedly higher glucose concentration $(\sim 70 \mathrm{mg} / \mathrm{dl}$ adult versus $20 \mathrm{mg} / \mathrm{dl}$ fetal) and may represent a reduction in insulin receptor number and/or affinity (29).

In conclusion, the results herein show that glucose utilization rate in the fetal lamb is regulated by both glucose and insulin concentrations. The glucose and insulin effects appear to be independent, producing additive effects on GUR. Thus, glucose utilization rate is not proportionate to a change in glucose concentration, accounting for a decreasing metabolic clearance rate at higher concentrations of glucose. These results describe the importance of both glucose and insulin in determining fetal GUR and also serve to emphasize that comparative studies of insulin and glucose metabolism among fetal sheep must be conducted at similar concentrations of glucose and insulin to avoid inaccurate estimates of their effects on glucose metabolism.

\section{REFERENCES}

1. Colwill JR, Davis JR, Meschia G, Makowski EL, Beck P, Battaglia, FC 1970 Insulin-induced hyperglycemia in the ovine fetus in utero. Endocrinology 87:710-715

2. Simmons MA, Jones MD Jr, Battaglia FC, Meschia G 1978 Insulin effect on fetal glucose utilization. Pediatr Res 12:90-92

3. Bloch CA, Banach W, Landt K, Devaskar S, Sperling MA 1986 Effects of fetal insulin infusion on glucose kinetics in pregnant sheep: a compartmental analysis. Am J Physiol 251:E448-E456

4. Hay WW Jr, Meznarich HK, Sparks JW, Battaglia FC, Meschia G 1985 Effect of insulin on glucose uptake in near-term fetal lambs. Proc Soc Exp Biol Med 178:557-564

5. Hay WW Jr, Meznarich $\mathrm{HK} 1986$ The effect of hyperinsulinemia on glucose utilization and oxidation and on oxygen consumption in the fetal lamb. Q J Exp Physiol 71:689-698

6. Bassett JM, Madill D 1974 The influence of maternal nutrition on plasma hormone and metabolite concentrations of fetal lambs. J Endocrinol 61:465477

7. Hay WW Jr, Sparks JW, Wilkening RB, Battaglia FC, Meschia G 1984 Fetal glucose uptake and utilization as functions of maternal glucose concentration. Am J Physiol 246:E237-E242

8. Philipps AF, Carson BS, Meschia G, Battaglia FC 1978 Insulin secretion in fetal and newborn sheep. Am J Physiol 235:E34-E38

9. Hay WW Jr, Sparks JW, Quissell BJ, Battaglia FC, Meschia G 1981 Simultaneous measurements of umbilical uptake, fetal utilization rate and fetal turnover rate of glucose. Am J Physiol 240:E662-E668

10. Hay WW Jr, Myers SA, Sparks JW, Wilkening RB, Meschia G, Battaglia FC 1983 Glucose and lactate oxidation rates in the fetal lamb. Proc Soc Exp Biol Med 173:553-563

11. Meschia G, Cotter JR, Breathnach CS, Barron DH 1967 Simultaneous measurement of uterine and umbilical blood flows and oxygen uptake. Q J Exp Physiol 52:1-8

12. Warnes DM, Seamark RF, Ballard FJ 1977 Metabolism of glucose, fructose and lactate in vivo in chronically cannulated foetuses and in suckling lambs. Biochem J 162:617-626

13. DeFronzo RA, Tobin JD, Andres R 1979 Glucose clamp technique: a method for quantifying insulin secretion and resistance. Am J Physiol 237:E214E223

14. Narahara HT, Ozand P 1963 Studies of tissue permeability. IX. The effect of insulin on the penetration of 3-methylglucose- $\mathrm{H}^{3}$ in frog muscle. J Biol Chem 238:40-49

15. Wardzala LJ, Jeanrenaud B 1981 Potential mechanism of insulin action on glucose transport in the isolated rat diaphragm. J Biol Chem 256:7090-7093

16. Gottesman I, Mandarino L, Verdonk C, Rizza R, Gerich J 1982 Insulin action increases the maximum velocity for glucose uptake without altering the 
Michaelis constant in man. J Clin Invest 70:1310-1314

17. Yki-Jarvinen H, Young AA, Lamkin C, Foley JE 1987 Kinetics of glucose disposal in whole body and across the forearm in man. J Clin Invest 79:17131719

18. Wilkening RB, Molina RD, Battaglia FC, Meschia G 1987 Effect of insulin on glucose/oxygen and lactate/oxygen quotients across the hindlimb of fetal lambs. Biol Neonate 51:18-23

19. Makowski EL, Schneider JM, Tsoulos NG, Colwill JR, Battaglia FC, Meschia G 1972 Cerebral blood flow, oxygen consumption, and glucose utilization of fetal lambs in utero. Am J Obstet Gynecol 114:292-303

20. Bristow J, Rudolph AM, Itskovitz J, Barnes R 1983 Hepatic oxygen and glucose metabolism in the fetal lamb. Responses to hypoxia. $\mathrm{J}$ Clin Invest 71:1047-1061

21. Jones CT, Rolph TP 1985 Metabolism during fetal life: a functional assessment of metabolic development. Physiol Rev 65:357-430

22. Zarlengo KM, Battaglia FC, Fennessey P, Hay WW Jr 1986 Relationship between glucose utilization rate and glucose concentration in preterm infants. Biol Neonate 49:181-189
23. Hodgson JC, Mellor DJ, Field AC 1980 Rates of glucose production and utilization by the foetus in chronically catheterized sheep. Biochem $J$ 186:739-747

24. Fowden AL 1980 Effects of adrenaline and amino acids on the release of insulin in the sheep fetus. J Endocrinol 87:113-121

25. Bergman RN, Finegood DT, Ader M 1985 Assessment of insulin sensitivity in vivo. Endocrinol Rev 6:45-86

26. Best JD, Taborsky GJ Jr, Halter JB, Porte D Jr 1981 Glucose disposal is not proportional to plasma glucose level in man. Diabetes 30:847-850

27. Hay WW Jr, Lin C, Meznarich HK, Battaglia FC, Meschia G 1984 Effect of high levels of insulin on glucose utilization and production in pregnant and nonpregnant sheep. Soc Gynecol Invest Annual Meeting (abstr 425)

28. Weeks TEC, Sasaki Y, Tsuda T 1983 Enhanced responsiveness to insulin in sheep exposed to cold. Am J Physiol 244:E335-E345

29. Kappy MS, Plotnick LP, Milley JR, Rosenberg A, Molteni RA, Jones MD Jr, Simmons MA 1981 Ontogeny of erythrocyte insulin binding in the sheep. Endocrinology 109:611-617 